\title{
Pathogenicity of a baculovirus infection causing white spot syndrome in cultured penaeid shrimp in Taiwan
}

\author{
Hsin-Yiu Chou ${ }^{1, * * *}$, Chang-Yi Huang ${ }^{1}$, Chung-Hsiung Wang ${ }^{2}$, \\ Hsien-Choung Chiang ${ }^{3}$, Chu-Fang Lo ${ }^{4, * *}$ \\ ${ }^{1}$ Department of Aquaculture, National Taiwan Ocean University, Keelung, Taiwan 20224, ROC \\ ${ }^{2}$ Department of Plant Pathology, National Taiwan University, Taipei, Taiwan 106, ROC \\ ${ }^{3}$ I-Lan Livestock Disease Control Center, I-Lan, Taiwan 260, ROC \\ ${ }^{4}$ Department of Zoology, National Taiwan University, Taipei, Taiwan 106, ROC
}

\begin{abstract}
Outbreaks of a disease causing serious losses among populations of cultured penaeid shrimp, including Penaeus monodon, P. japonicus and P. penicillatus, in Taiwan are characterized by obvious white spots on the carapace, appendages and the inside surface of the body. For this reason, we propose the name 'white spot syndrome' (WSS). Healthy juvenile kuruma shrimp $P$. japonicus were exposed by immersion to epidermal filtrate from diseased $P$. japonicus and $P$. monodon which exhibited marked white spot signs. These experimentally infected shrimp resembled the spontaneously infected ones. Cumulative mortalities reached $100 \%$ within 5 to $7 \mathrm{~d}$ and were significantly affected by catching and temperature stress. A non-occluded rod-shaped viral particle was found by electron microscopy in the epidermis of both spontaneously and experimentally infected kuruma shrimp. Virions were enveloped, $330 \pm 20 \mathrm{~nm}$ in length and $87 \pm 7 \mathrm{~nm}$ in diameter. The close resemblance in external signs and viral morphology between spontaneously diseased and experimentally infected shrimp indicated that the rod-shaped virus may be the main causative agent of the disease characterized by white spot syndrome in Taiwan.
\end{abstract}

KEY WORDS: Baculovirus · Pathogenicity · Penaeid shrimp - White spots - Taiwan

\section{INTRODUCTION}

Since 1992, outbreaks of a new disease leading to serious mortality among populations of cultured kuruma shrimp Penaeus japonicus have occurred in northern Taiwan. The disease is characterized by obvious white spots on the carapace, appendages and the inside surface of the body, and cumulative mortality reaches $100 \%$ within 2 to $7 \mathrm{~d}$. The diseased shrimp also display signs of lethargy and reddish coloration of the hepatopancreas. In 1993, white spot syndrome (WSS) in cultured giant tiger prawn $P$. monodon and redtail prawn $P$. penicillatus was observed. Serious damage to penaeid shrimp production from WSS in Taiwan has been reported (M. C. Tung, J. H. Chen, G. H. Cheng pers. comm.).

•E-mail: hychou@ntou66.ntou.edu.tw

- Addressees for reprint requests
An epizootiological survey of kuruma shrimp in Japan reported similar findings (Nakano et al. 1994). According to the evidence from electron microscopy and the results of challenge tests with the filtrate from diseased shrimp lymphoid organs, the causative agent was a virus that was temporarily designated RV-PJ, a rod-shaped nuclear virus of Penaeus japonicus (Inouye et al. 1994, Takahashi et al. 1994).

To date, the prevalence of baculoviruses in cultured penaeid shrimps has been well documented (Lightner 1983, 1985). Among these penaeid baculoviruses, monodon baculovirus (MBV), baculoviral mid-gut necrosis virus (BMNV), Baculovirus penaei (BP) and yellowhead disease virus (YHV) were considered to be the most important because they have on occasion caused serious losses in infected shrimp populations (Couch 1974, Lightner \& Redman 1981, Sano et al. 1981. Lightner et al. 1983,1987, Boonyaratpalin et 
al. 1993). The penaeid shrimps of Southeast Asia are severely threatened by viral infection.

Baculovirus-like viral particles were observed in the penaeid shrimp spontaneously diseased with WSS (Tung et al pers. comm.). This virus may possibly be the main causative agent for the WSS that has occurred in Taiwan in penaeid shrimp. The present study describes our electron microscope observations of diseased shrimp. A filtrate was made from the epidermis of these diseased shrimp and the presence of viral particles was confirmed by negative staining. Direct inoculation of this virus-containing filtrate into fish cell lines showed no cytopathic effect. Challenge tests used this filtrate on different sized kuruma shrimp. The effects of catching and temperature stress were also investigated.

\section{MATERIALS AND METHODS}

Shrimp. Diseased kuruma shrimp were collected from a culture farm at Wu-Chieh in I-Lan Prefecture in northern Taiwan. The healthy kuruma shrimp used for challenge tests were obtained from a hatchery and a shrimp farm in southern Taiwan where no viral disease had been reported. All of the kuruma shrimp were maintained in aerated 25 to $28^{\circ} \mathrm{C}$ aquaria and fed on artificial, commercially obtained shrimp food twice daily.

Light microscopy. Both normal kuruma shrimp and individuals displaying marked white spot signs were preserved in Davison's fixative (Bell \& Lightner 1988). After 48 h in Davison's fixative, specimens were transferred to $50 \%$ ethanol, then processed routinely for histology to $5 \mu \mathrm{m}$ paraffin wax sections, and stained routinely with hematoxylin and eosin (H\&E).

Transmission electron microscopy. Samples of the epidermis covering the gill chamber underneath the carapace were removed from naturally and experimentally infected live kuruma shrimp, and immediately prefixed in $2.5 \%$ glutaraldehyde in $0.1 \mathrm{M}$ cold phosphate buffer solution (PBS, $\mathrm{pH} 7.4$ ) for $2 \mathrm{~h}$ at $4^{\circ} \mathrm{C}$. Subsequently, samples were washed several times in cold PBS, then postfixed in $1 \%$ osmium tetroxide for $3 \mathrm{~h}$ at $4^{\circ} \mathrm{C}$. The samples were dehydrated and embedded in Spurr's resin. Ultrathin sections were prepared on a Reichert-Jung Ultracut-E ultratome, and stained with uranyl acetate and lead citrate. The sections were observed with a Hitachi $\mathrm{H}-600$ transmission electron microscope.

Negative staining. The epidermis from infected Penaeus monodon was removed and homogenized in brackish water at $4^{\circ} \mathrm{C}$ at a ratio of $1: 9$. After being centrifuged at $8510 \times g$ (Sigma $2 \mathrm{~K} 15$ rotor 12141 ) for 5 min, the supernatant fluid was filtered through a
$0.45 \mu \mathrm{m}$ membrane. The filtrate was centrifuged at $14549 \times g$ (Sigma 2 K15 rotor 12139) for $1.5 \mathrm{~h}$ and the resulting pellet was resuspended in sterilized brackish water prior to negative staining. For negative staining, 1 drop of suspension was mixed with 4 drops of the mixture of $0.1 \%$ bovine serum albumin and $2 \%$ phosphotungstic acid $(1: 2, \mathrm{pH} 7.0)$. The mixture was placed on a grid for 30 to $60 \mathrm{~s}$ and excess suspension was removed with filter paper. The preparation was allowed to dry before being examined. The result was observed under a Hitachi H-600 transmission electron microscope.

Cytopathology assay. EPC (epithelioma papulosum cyprini), CHSE-214 (chinook salmon embryo), FHM (fathead minnow) and SSE-5 (sockeye salmon embryo) cells were seeded in 24 -well microplates. A filtrate was made from the epidermis of the diseased shrimp and was diluted from $1 / 20$ to $1 / 12500$ in 5 -fold dilutions. Diluted solutions were inoculated into the 4 fish cell lines and these cells were observed over $2 \mathrm{wk}$ at an incubation temperature of $20^{\circ} \mathrm{C}$.

Challenge test I. An infection trial was performed using the filtrate of the epidermis from live or frozen naturally infected Penaeus japonicus and $P$. monodon. The filtrate was diluted 500 to 750 times in brackish water in order to be used as a waterborne inoculum. Two replicates of 35 juvenile kuruma shrimp (1 mo old, mean weight $0.08 \mathrm{~g}$ ) were immersed in these diluted filtrates for $2 \mathrm{~h}$. Two other populations were similarly exposed, either to the filtrate from healthy $P$. monodon epidermis or to Grace's insect medium: these served as controls. After inoculation, shrimp were kept in aerated glass aquaria. Water temperature and salinity were 25 to $28^{\circ} \mathrm{C}$ and 25 to $30 \mathrm{ppt}$, respectively, throughout the experiment. Mortality was observed daily and moribund shrimp were collected and examined by transmission electron microscopy.

Challenge test II. Infection trials using 3 different sized groups of juvenile kuruma shrimp proceeded as above. Twenty to thirty juvenile kuruma shrimp (mean weights $0.08,0.16$ and $0.26 \mathrm{~g}$ ) were exposed for $1 \mathrm{~h}$ to inoculum from diseased Penaeus japonicus prepared as above and then kept in aerated glass aquaria. Water temperature and salinity were 25 to $28^{\circ} \mathrm{C}$ and 25 to 30 ppt, respectively, throughout the experiment. Mortality was observed daily.

Effect of catching stress on experimental infection trials. Catching stress was applied to juvenile kuruma shrimp ( $\mathrm{n}=20$, mean weight $0.16 \mathrm{~g}$ ) after exposure to brackish water only or to the inoculum from diseased Penaeus japonicus prepared as above. After transfer to glass aquaria, shrimp of experimental and control groups were caught by net and transferred to another glass aquarium once a day. Mortalities were recorded daily, 
Effect of temperature stress on experimental infection trials. Twenty juvenile kuruma shrimp (mean weight $0.16 \mathrm{~g}$ ) were transferred to $33^{\circ} \mathrm{C}$ after $1 \mathrm{~h}$ of exposure at room temperature $\left(25\right.$ to $\left.28^{\circ} \mathrm{C}\right)$ to the inoculum from diseased Penaeus japonicus prepared as above. A control group was exposed to brackish water at room temperature for $1 \mathrm{~h}$ and then transferred to $33^{\circ} \mathrm{C}$. The shrimp were observed daily for mortality

\section{RESULTS}

\section{Light microscopy}

The typical external signs of spontaneously diseased Penaeus monodon and P. japonicus in these outbreaks are the obvious white spots on the carapace, appendages and the inside surface of the body (Fig. 1A, B).

\section{A}
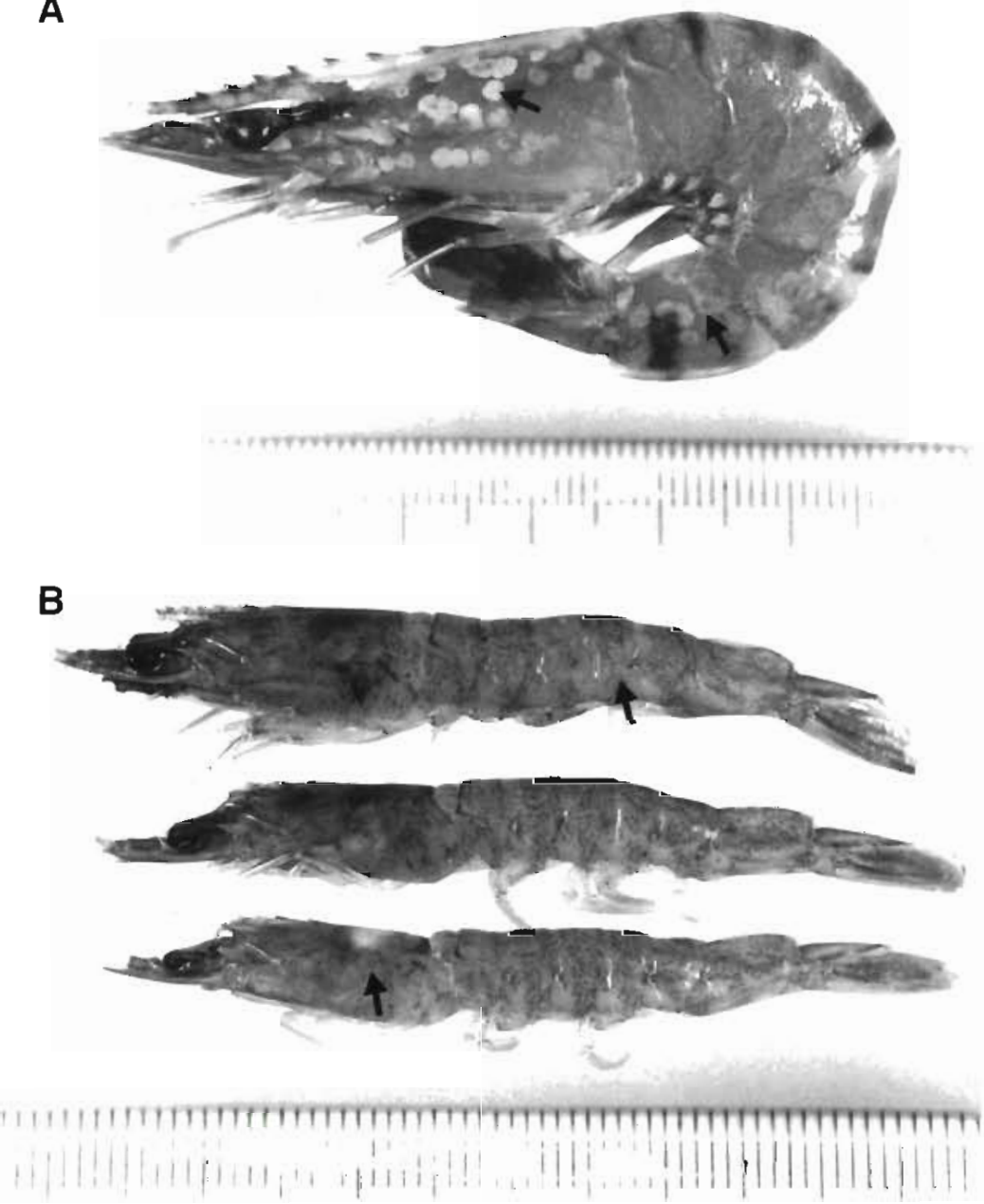

Fig. 1. External appearance of spontaneously diseased (A) Penaeus monodon and (B) P. japonicus cultured in Taiwan. White spots (arrows) appear on the carapace and surface of the body
Histopathological changes in tissues from kuruma shrimp naturally infected with white spot syndrome were observed (Fig. 2A to F). Degenerated cells characterized by hypertrophied nuclei were observed in the cuticular epidermis and connective tissue. Cellular necrosis and detachment of intestinal epithelium tissue were also observed. Fig. 2F shows severe atrophy of the hepatopancreas in these diseased shrimp.

\section{Transmission electron microscopy}

The ultrathin sections of the underlying epidermis of the cuticle from spontaneously diseased and experimentally infected kuruma shrimp revealed numerous non-occluded, enveloped viral particles with rodshaped morphology (Fig. 3A, B). The viral particles were $330 \pm 20 \mathrm{~nm}$ in length and $87 \pm 7 \mathrm{~nm}$ in diameter $(n=30)$. The electron-dense central core of the viral particle was nucleocapsid, approximately $220 \times 70 \mathrm{~nm}$ in size. Rod-shaped virions as large aggregations in the nuclei of infected epithelial cells were also examined under transmission electron microscopy (Fig. 4). No differences in virion morphology between spontaneously diseased and experimentally infected shrimp were recognized.

\section{Negative staining and cytopathology assay}

The result of negative staining of the pellet from the filtrate of diseased Penaeus monodon epidermis is shown in Fig. 5. Viral particles with rodshaped morphology can be seen. These are similar to the viral particles observed in ultrathin sections of spontaneously diseased shrimp. No bacteria were observed.

Cytopathic effects were not found in any of the 4 tested fish cell lines; the filtrate which was used as a waterborne inoculum had no cytotoxicity.

\section{Challenge test}

Healthy shrimp were exposed to epidermal filtrate from diseased Penaeus japonicus and $P$. monodon which exhibited marked white spot symptoms. 


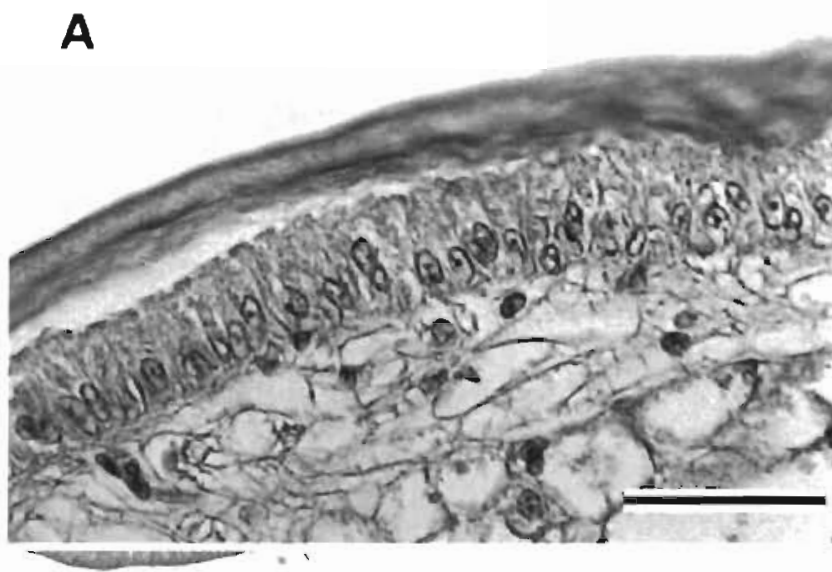

B

$=\mathrm{C}$.
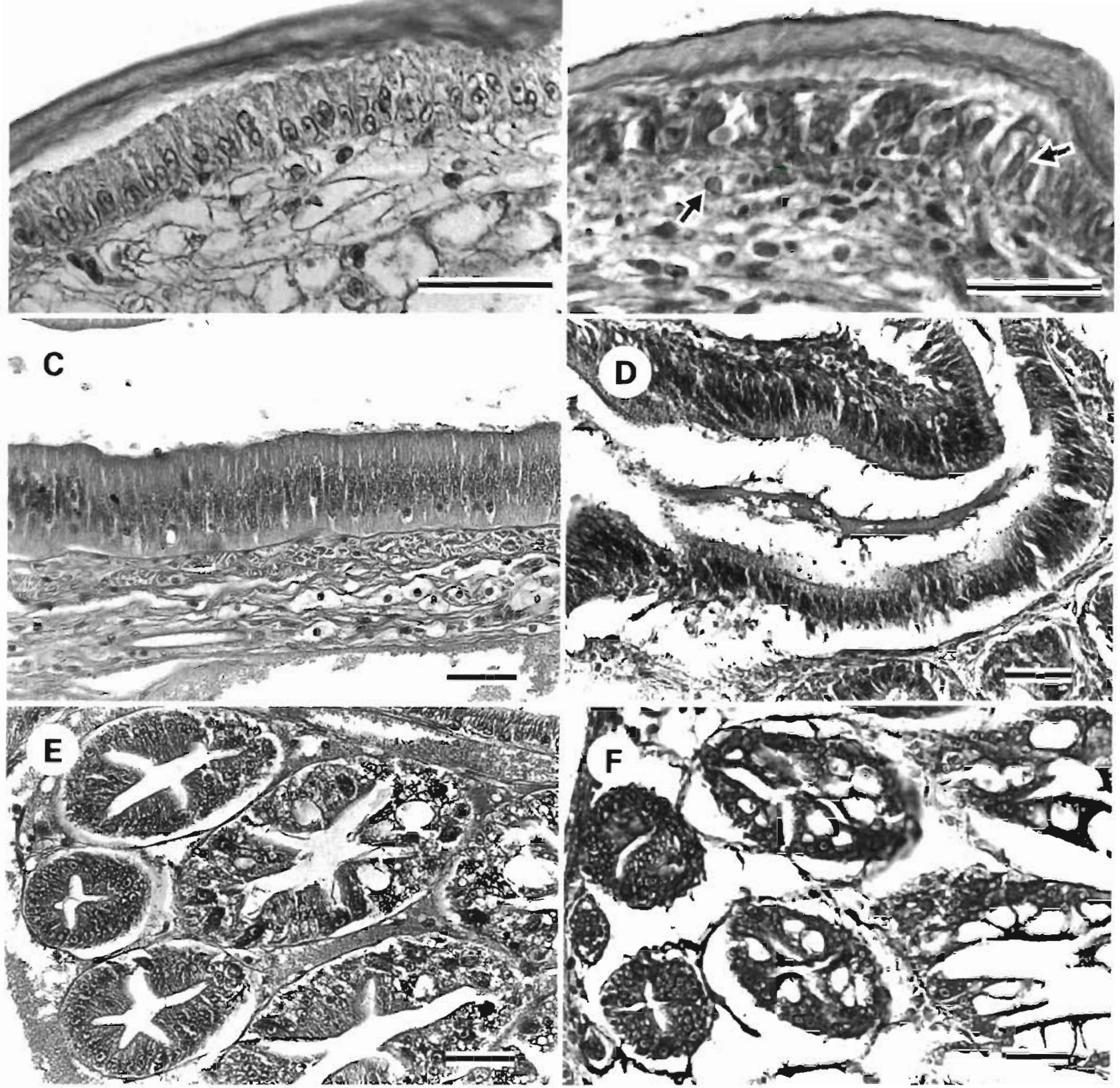

Fig. 2. Penaeus japonicus. Histopathological changes in the tissues of kuruma shrimp naturally infected with white spot syndrome. $(A, B)$ Cuticular epidermis of normal and diseased shrimp. Degenerated cells characterized by hypertrophied nuclei (arrows) were observed in the cuticular epidermis and connective tissue. (C) Normal intestinal tissue compared with (D) cellular necrosis and detachment of intestinal epithelium tissue in diseased shrimp. (E, F) Hepatopancreas of normal and diseased shrimp. Severe atrophy of the hepatopancreas in the diseased shrimp was observed. H\&E. Scale bars $=40 \mu \mathrm{m}$

These experimentally infected shrimp resembled the spontaneously affected ones (Fig 6), and cumulative mortalities reached $100 \%$ within 5 to $7 \mathrm{~d}$ (Fig. 7), while no shrimp died in the control groups. As Fig. 8 shows, the inoculum from diseased $P$. japonicus was highly pathogenic to the smallest shrimp tested (mean weight $0.08 \mathrm{~g}$ ); all of these shrimp died within $5 \mathrm{~d}$. Only $35 \%$ cumulative mortality was found in the $0.16 \mathrm{~g}$ shrimp group after $7 \mathrm{~d}$, although mortality reached $100 \%$ in 12 d. $10 \%$ mortality was observed in the group of 


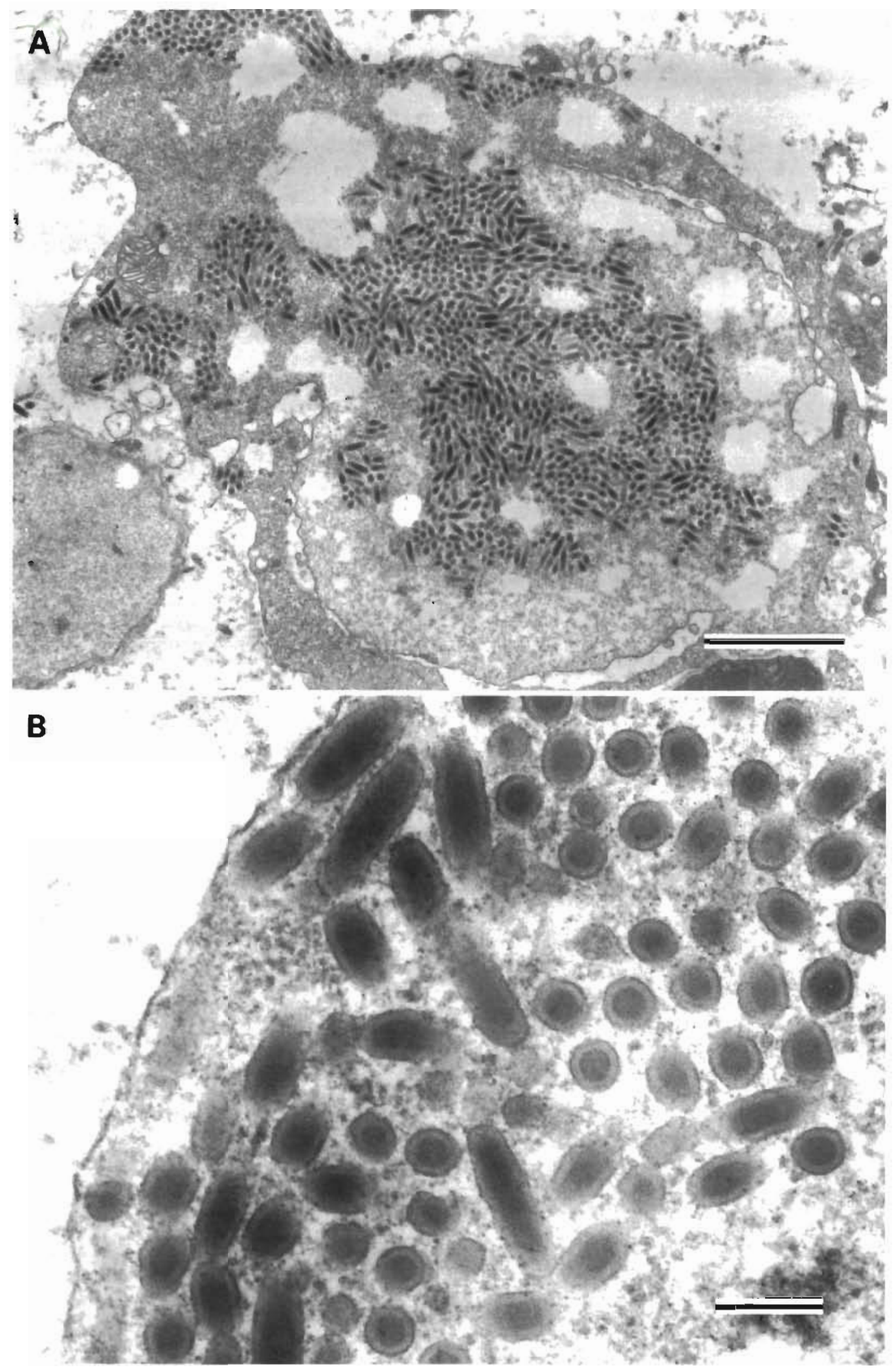

Fig. 3. Penaeus japonicus. Epidermis of shrimp spontaneously diseased with white spot syndrome. (A) Observed aggregation of viral particles in the nucleus and in the cytoplasm. Scale bar $=2 \mu \mathrm{m}$. (B) High magnification of viral particles with rod-shaped morphology in nucleus. Scale bar $=200 \mathrm{~nm}$ 


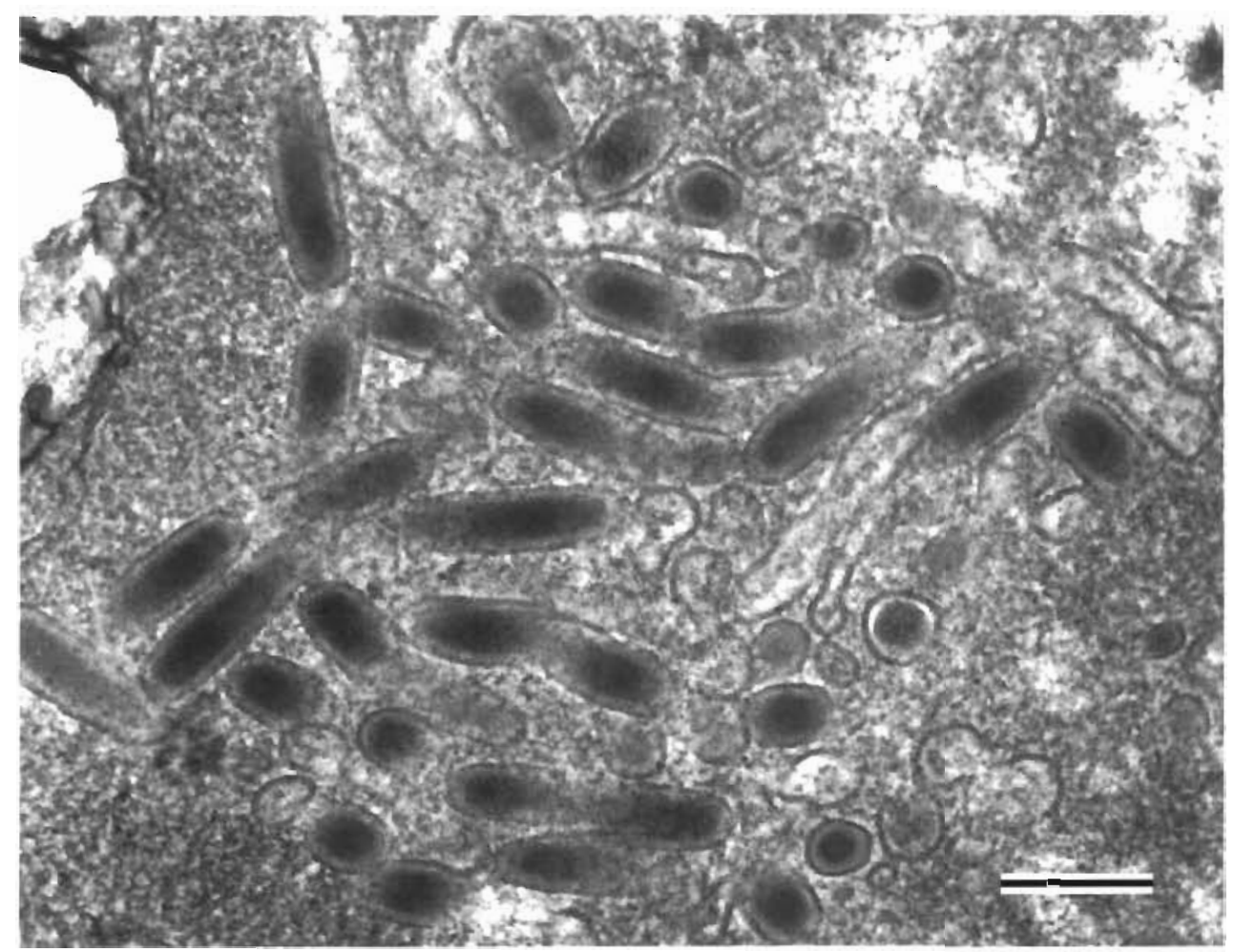

Fig. 4. Penaeus japonicus. Rod-shaped viral particles in the epidermis of shrimp experimentally infected with the filtrate obtained from diseased $P$. monodon. Scale bar $=200 \mathrm{~nm}$

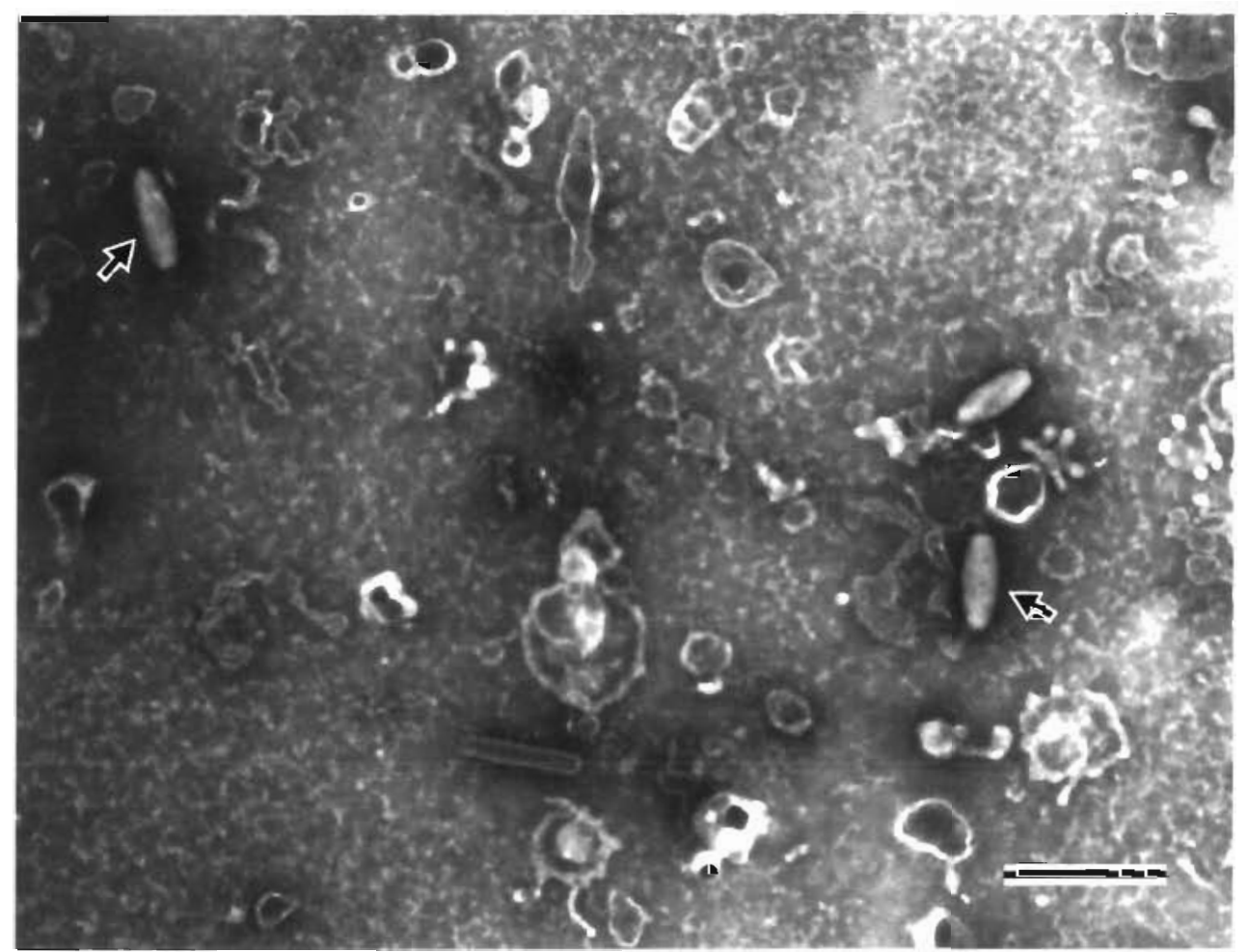

Fig. 5. Penaeus monodon. Negatively stained micrograph of the pellet from filtrate of diseased giant tiger shrimp epidermis. Viral particles (arrows) with rod-shaped morphology were observed. Scale bar $=500 \mathrm{~nm}$ 


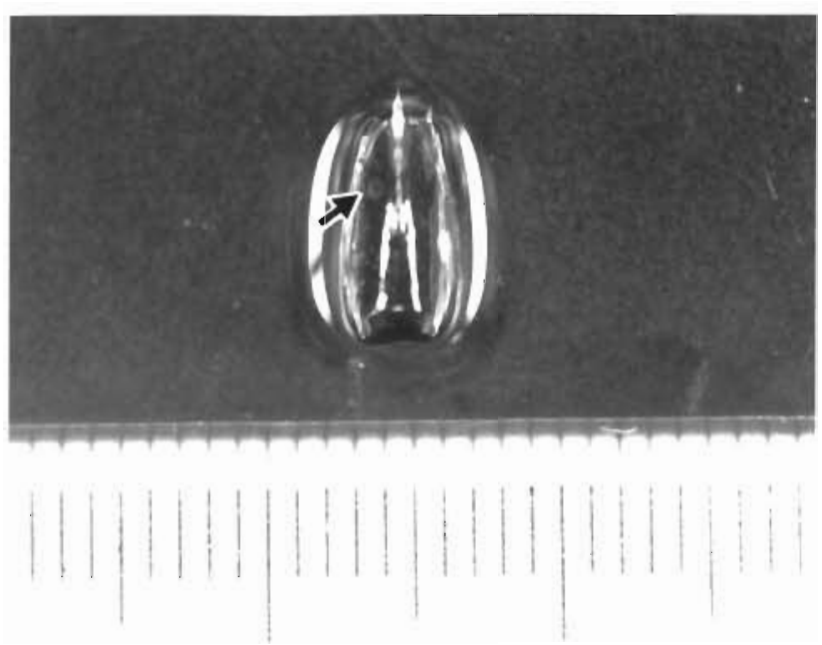

Fig. 6. Penaeus japonicus. White spot (arrow) on the removed carapace of experimentally infected shrimp

largest shrimp (mean weight $0.26 \mathrm{~g}$ ) within $2 \mathrm{wk}$. No shrimp died in the control groups. Accordingly, the $0.16 \mathrm{~g}$ shrimp were chosen to estimate the effect of stress.

\section{Effect of stress on experimental infection trials}

The results presented in Fig 9 show the effect of catching and temperature stress on experimental infection trials. The shrimp in the experimental group under catching stress began to die $1 \mathrm{~d}$ after inocula-

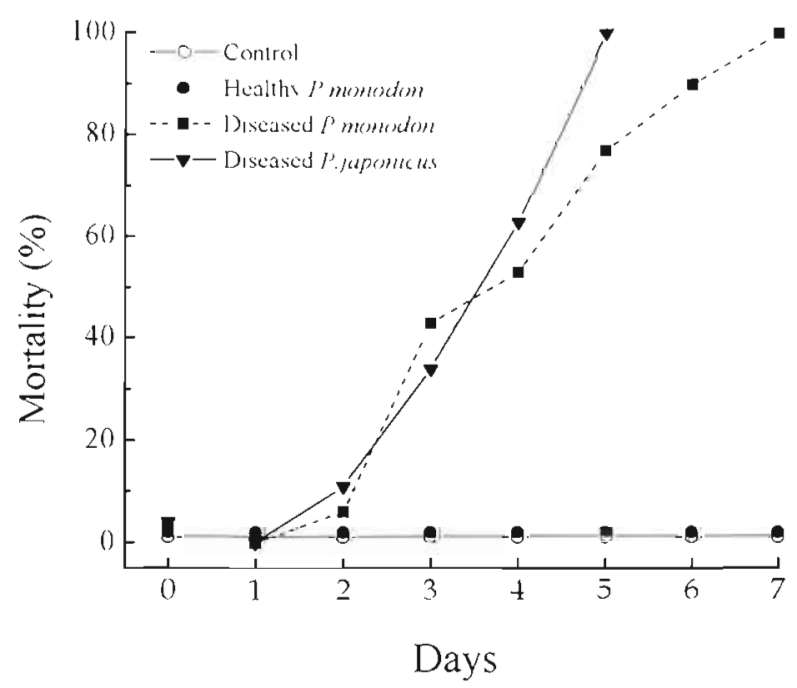

Fig. 7. Penaeus japonicus. Cumulative mortalities (\%) of shrimp (0.08 g average weight) experimentally infected by immersion in filtrates from diseased $P$. japonicus and $P$. monodon contrasted with healthy shrimp control groups

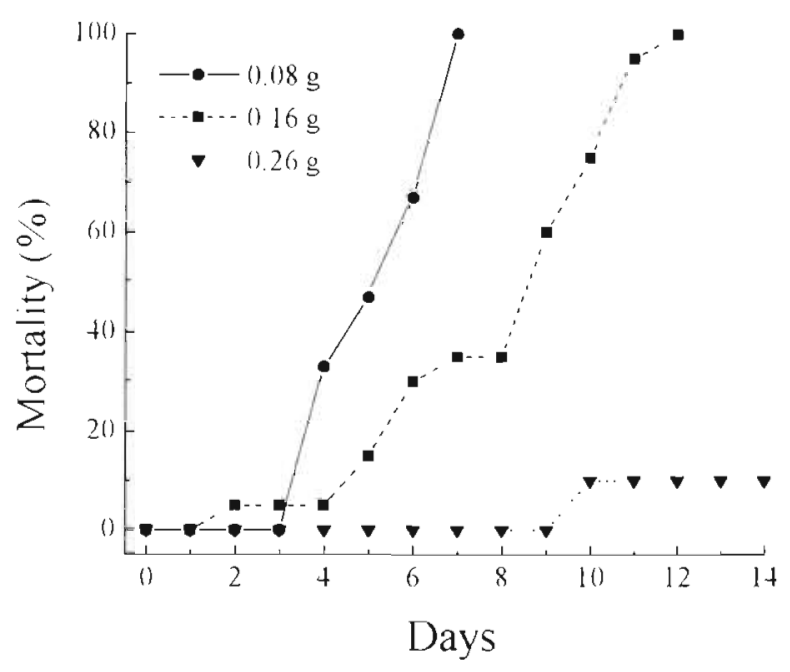

Fig. 8. Penaeus japonicus. Cumulative mortalities $(\%)$ of different sized groups of juvenile shrimp $(0.08,0.16$ and $0.26 \mathrm{~g}$ average weight) experimentally infected by immersion in filtrates from diseased $P$. japonicus

tion, and cumulative mortality reached $80 \%$ within $7 \mathrm{~d}$. Mortality among the experimentally infected shrimp under temperature stress reached $90 \%$ within $7 \mathrm{~d}$. Only $35 \%$ mortality was observed in the experimentally infected shrimp without stress. However, no shrimp died in the control groups, whether stressed or not

\section{DISCUSSION}

Disease outbreaks among cultured penaeid shrimp due to white spot syndrome have been observed in Taiwan since early 1992. The diseased shrimp have obvious white spots on the carapace, appendages and the inside surface of the body, and also display signs of lethargy and reddish coloration of the hepatopancreas. Thus, in this paper, we propose the name 'white spot syndrome' (WSS).

Vibriosis, viral infection, poor environmental management and nutrient imbalance have all been conjectured to be the possible cause for these outbreaks (S. N. Chen, S. L. Huang, J. S. Uang, J S. Wang, W. Y Liou \& G. H. Kou pers. comm.). Based on electron microscope observation, however, a rod-shaped virus was considered to be the main causative agent. In the present study, the pathogenicity of a virus from diseased Penaeus japonicus and $P$. monodon with white spot syndrome was investigated. Close resemblance of white spot signs and viral morphology between spontaneously diseased and experimentally infected shrimp demonstrated that this virus is indeed the causative agent of the outbreak. The virus is highly 


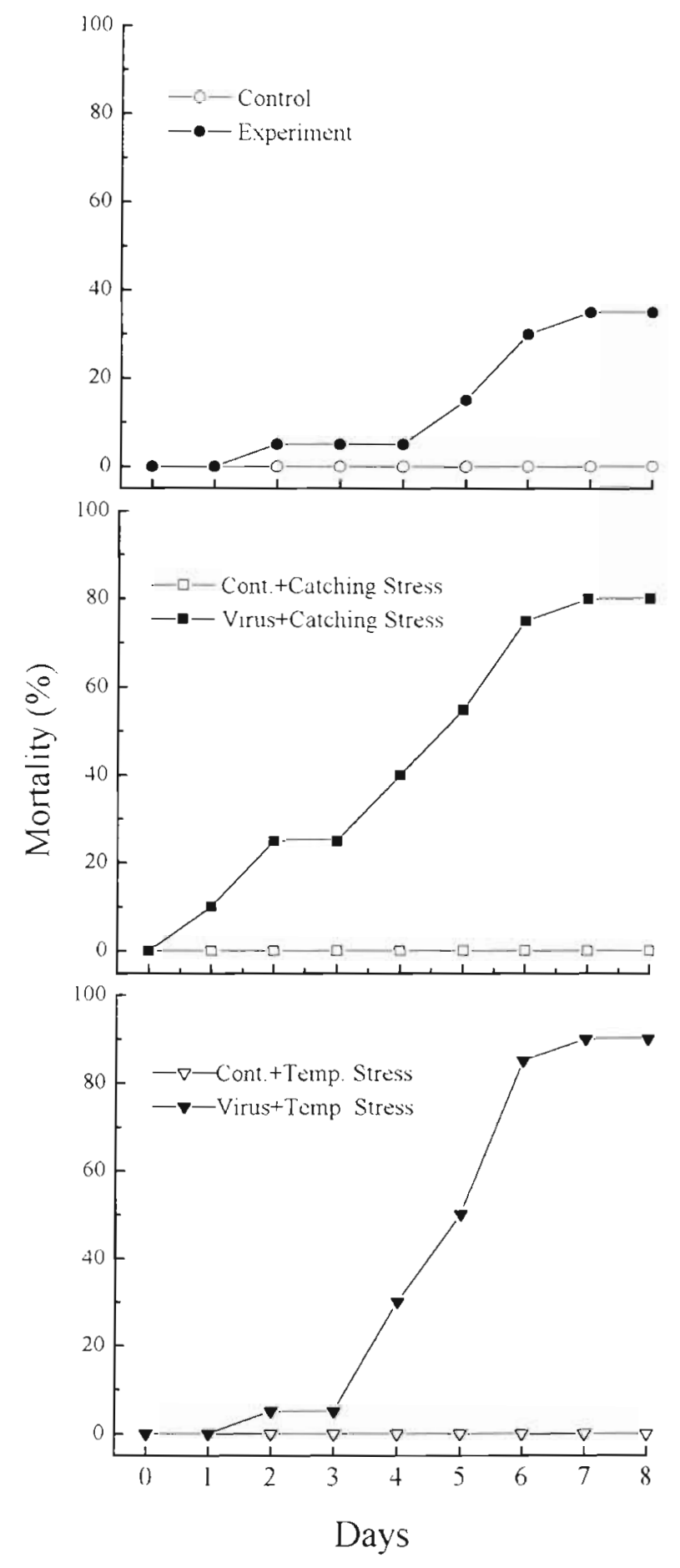

Fig. 9. Penaeus japonicus. Effect of catching and temperature stress on cumulative mortalities (\%) of juvenile shrimp $(0.16 \mathrm{~g}$ average weight) experimentally infected by immersion in filtrates from diseased $P$. japonicus

pathogenic and constitutes a threat to shrimp. Informal pilot studies in which diseased shrimp were fed to healthy specimens suggest that the virus may be transmitted orally as well as via water
In Japan, a serious disease causing white spots on the body of cultured kuruma shrimp continues to be reported. Serious damage to kuruma shrimp production has occurred and many shrimp farms in western Japan have temporarily been forced to close (Nakano et al. 1994). Moreover, the causative agent was considered to be a virus that was shipped with imported kuruma shrimp from China (Momoyama et al. 1994). Outbreaks of WSS amongst penaeid shrimp are evidently not a confined, local problem anymore. It has already brought the cultured shrimp industry in Asia to a critical condition.

In order to classify the causative virus more clearly and develop a quick diagnostic method, data on the physicochemical characterization of this agent are necessary. Little data on the characteristics of crustacean baculoviruses exist. BP and MBV are the only 2 crustacean baculoviruses that have been characterized (Summers 1977, Mari et al. 1993). The absence of marine crustacean cell lines and problems in the purification of viruses are barriers to this study. In the present paper, we attemped to make a pellet of the agent from homogenate of infected shrimp and preliminary success was shown by the negatively stained virions from the products. Further studies need to be performed to purify the agent more effectively and to increase virus yield from the purification technique, as well as to determine the DNA structure and other specific characteristics of this virus. Furthermore, comparisons of the causative rod-shaped virus with other shrimp baculoviruses are required to establish whether the WSS-associated virus is really a new agent, or a mutation of an already known virus.

Acknowledgements. The authors express their appreciation to Mr W. B. Yu and Mr W. T Hong, I-Lan Livestock Disease Control Center, for sampling assistance.

\section{LITERATURE CITED}

Bell TA, Lightner DV (1988) A handbook of normal penaeid shrimp histology. World Aquaculture Society, Baton Rouge

Boonyaratpalin S, Supamataya K, Kasonchandra J, Direkbusaracom $\mathrm{S}$, Ekpanithanpong $U$, Chantanachooklin $\mathrm{C}$ (1993) Non-occluded baculo-like virus, the causative agent of yellow head disease in the black tiger shrimp (Penaeus monodon). Fish Pathol 28:103-109

Couch JA (1974) An enzootic nuclear polyhedrosis virus of pink shrimp: ultrastructure, prevalence, and enhancement. J Invertebr Pathol 24:311-331

Inouye K, Miwa S, Oseko N, Nakano H, Kimura T (1994) Mass mortalities of cultured kuruma shrimp. Penaeus japonicus, in Japan in 1993: electron microscopic evidence of the causative virus. Fish Pathol 29:149-158 (in Japanese)

Lightner DV (1983) Diseases of cultured penaeid shrimp. In: McVey JP (ed) Mariculture. CRC Press, Boca Raton, p 289-320 
Lightner DV (1985) A review of the diseases of cultured penaeid shrimps and prawns with emphasis on recent discoveries and developments. In: Taki Y et al (eds) Proceedings of the First International Conference on the Culture of Penaeid Prawns/Shrimps. SEAFDEC Aquaculture Department, Manila, p 79-103

Lightner DV, Hedrick RP. Fryer JL, Chen SN, Lado IC, Kou GH (1987) A survey of cultured penaeid shrimp in Taiwan for viral and other important diseases. Fish Patho] 22:127-140

Lightner DV, Redman RM (1981) A baculovirus-caused disease of the penaeid shrimp, Penaeus monodon. J Invertebr Pathol 38:299-302

Lightner DV, Redman RM, Bell TA (1983) Observations on the geographic distribution, pathogenesis and morphology of the baculovirus from Penaeus monodon Fabricius. Aquaculture 32:209-233

Mari J, Bonami JR, Poulos B, Lightner D (1993) Preliminary characterization and partial cloning of the genome of a baculovirus from Penaeus monodon (PmSNPV $=\mathrm{MBV}$ ). Dis aquat Org 16:207-215

Responsible Subject Editor: J. E. Stewart, Dartmouth, Nova Scotia, Canada

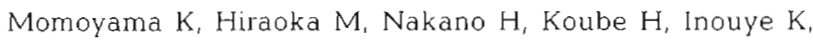
Oseka $N$ (1994) Mass mortalities of cultured kuruma shrimp, Penaeus japonicus, in Japan in 1993: histopathological study. Fish Pathol 29:141-148 (in Japanese)

Nakano H, Koube H, Umezawa S, Momoyama K, Hiraoka M, Inouye K, Oseko N (1994) Mass mortalities of cultured kuruma shrimp, Penaeus japonicus, in Japan in 1993 epizootiological survey and infection trials. Fish Pathol 29:135-139 (in Japanese)

Sano T, Nishimura T, Oguma K, Momoyama K, Takeno $N$ (1981) Baculovirus infection of cultured kuruma shrimp Penaeus japonicus in Japan. Fish Pathol 15:185-191

Summers MD (1977) Characterlzation of shrimp baculovirus. Ecological Research Series 600/3-77-130, US Environmental Protection Agency, Washington, DC

Takahashi Y, Itami T, Kondo M, Maeda M, Fujii R, Tomonaga S, Supamattaya K, Boonyaratpalin $S$ (1994) Electron microscopic evidence of bacilliform virus infection in kuruma shrimp (Penaeus japonicus). Fish Pathol 29: $121-125$

Manuscript first received: February 17, 1995

Revised version accepted: May 30, 1995 